\title{
Synthesis of $\beta$-Glucan nanoparticles from red algae derived $\beta$-Glucan for potential biomedical applications
}

Parthasarathy Ramalingam ( $\nabla$ sarathy20bioinfo@gmail.com )

Indian Institute of Science https://orcid.org/0000-0002-1840-9678

Prabu kumar Seetharaman

Bharathidasan University

Yashavantha Rao H.C.

Indian Institute of Science

Jayabaskaran Chelliah

Indian Institute of Science

\section{Research Article}

Keywords: Gracilaria corticate (Gco), $\beta$-Glucan nanoparticles, anticancer activity, Antibacterial activity, dual staining, DNA fragmentation assay

Posted Date: April 12th, 2021

DOI: https://doi.org/10.21203/rs.3.rs-354194/v1

License: (9) This work is licensed under a Creative Commons Attribution 4.0 International License. Read Full License 


\section{Abstract}

The present study highlighted that the synthesis of $\beta$-Glucan nanoparticles ( $\beta$-GluNPs) developed as a facile method to prevent cancer and infectious diseases, which is highly effective and inexpensive in the biological field. This research study has demonstrated the use of marine algae (Gracilaria corticate) to extract water-soluble $\beta$-Glucan and synthesis of $\beta$-GluNPs by dissolving the extracted $\beta$-Glucan in $\mathrm{NaOH}$ under optimal conditions. The molecular structure of the extracted and stabilized $\beta$-GluNPs was analysed using NMR. Further, the Physico-chemical parameters of $\beta$-GluNPs were analysed by the high throughput instruments like UV spectroscopy, FTIR, DLS, ZETA Potential, SEM, HRTEM, and XRD analysis. The synthesis of $\beta$-GluNPs confirmed by IR spectroscopy. The HR-TEM results demonstrated that the formation of polydispersed nanoparticles with a mean size of $20 \pm 5 \mathrm{~nm}$. The hydrostatic zeta potential was $-22.7 \mathrm{mV}$, which indicated their colloidal stability. The XRD pattern revealed the crystalline nature of the nanoparticles. Besides, $\beta$-GluNPs performed better antibacterial activity against the tested pathogens. The apoptosis and DNA fragmentation observed to be $\mathrm{IC}_{50} 42.5 \mu \mathrm{g} / \mathrm{ml}$ of the $\beta$-GluNPs. The DNA fragmentation assay indicated the selective inhibition of the MCF-7 cell line by DNA damage. Hence, $\beta$ GluNPs used as a promising alternative drug against human breast cancer.

\section{Introduction}

Recently, the researchers were focusing on green synthesis and eco-friendly platform biomaterials [1]. The optimal green synthesized biomaterials are non-toxic and excellent biocompatibility. Nano biomedicine is quite a novel area that synthesis and applies nanosize biomaterials for biomedical applications. The conventional microbial producing polysaccharides are very effective due to their negative charge, which interacts with positively charged compounds [2]. Consequently, it allows different natural functionalities $[3,4]$.

Marine algal based $\beta$ Glucan i.e. polysaccharides made up of glucose present in red, green, and brown algae seaweeds are starch and cellulose, cellulose and laminarin and cellulose and floridean starch, respectively that are considered as superior bioactive molecules in biomedical science $[5,6]$. Besides, epidemiological and clinical trials alleged that marine algae $\beta$-glucan is an immunostimulant and a potential antitumor drug $[7,8]$. In recent years, the nanoparticles have been synthesized using polysaccharides such as chitosan and Glucan [9-11]. Glucans, a class of natural polysaccharides, are glycosidic bonds and differing degrees of branching from marine algae sources [12]. Biologically derived $\beta$-Glucans have potential antimicrobial properties against viral, bacterial, parasitic, and fungal pathogens [13]. Many researchers reported that the administration of natural $\beta$-Glucan could inhibit bacterial pathogens and increase cytokines, monocytes, and neutrophils $[14,15]$.

Cancer is presently one of the main diseases responsible for human mortality and morbidity, which cause health and economic burdens. Cancer treatment is commonly based on chemotherapy and resistance to common chemotherapeutic agents and hazardous side effects highlight the importance of hunting for potent anticancer drugs. Hence, new drugs that improve cancer curability without any side effects on the 
host system are needed $[16,17]$. Plant derived drugs such as taxol and camptothecin have been used as anticancer drugs that bear high costs, and cannot be afforded by a common man [18]. Thus, new approaches and sources to find alternative drugs that are effective and inexpensive are in focus.

Nanotechnology is rapidly emerging with its biological science application and recently, in medical science [19]. Nanoparticles (NPs) are explored in cancer biology (which leads to a separate discipline as nanooncology) to diagnose and treat human cancers $[20,21]$. The utilization of NPs will facilitate both tumor targeting and drug delivery in a distinct way [22]. Recent studies have confirmed that specially formulated metal NPs have shown anticancer activities [23,24]. The potential adverse effects of NPs on biological systems due to the unpredicted nature of metal NPs has raised questions about their applications in humans [25]. Therefore, the selection of nanomaterials for applications within the field could also be a challenge as materials that are biodegradable, biocompatible, and non-toxic are desirable [26]. Nanoparticles synthesized from biopolymer bases possess advantages such as availability from replenishable marine algal resources, biodegradability, and biocompatibility [24].

Therefore, the present study was to biosynthesize water-soluble $\beta$-Glucan nanoparticles using Gracilaria Salicornia (Gco) marine algae and the as prepared nanoparticles evaluated for their anticancer potential against breast cancer (MCF-7) cell line under in vitro conditions and antibacterial activity against bacterial pathogens. This biological strategy is a cost-effective and an alternative approach to the conventional chemical and physical methods of synthesis.

\section{Material And Methods}

\section{Extraction of $\beta$-glucan from Gracilaria corticate (Gco)}

The red algae (Gco) were collected from the Bay of Bengal, Mandabam, Rameswaram Tamil Nadu, India. The algae were cleaned with double distilled water to remove excess debris and were allowed to completely dry. The dried algae $(50 \mathrm{~g})$ were extracted with $0.1 \mathrm{M}$ Hydrochloric acid (HCL) for $2 \mathrm{~h}$ at $60^{\circ} \mathrm{C}$. At the end of $2 \mathrm{~h}$, the algal extracts were naturalized and spun in a centrifuge at $5000 \mathrm{rpm}$. Then, the supernatant was collected and dried by using a rotary evaporator at $60^{\circ} \mathrm{C}$. The dried powder washed with MilliQ water to remove excess debris and stored at $15^{\circ} \mathrm{C}$ for further characterization and biological activity studies.

\section{Synthesis of $\beta$-GluNPs}

Typically, $1 \mathrm{~g}$ of $\beta$-Glucan dissolved in $100 \mathrm{ml}$ of $2 \%$ Sodium hydroxide $(\mathrm{NaOH})$ in a magnetic stirrer for $3 \mathrm{~h}$ at $90^{\circ} \mathrm{C}$. After incubation, $\beta$-Glucan nanoparticles ( $\beta$-GluNPs) were precipitated by adding $1 \%$ acetic acid. The synthesized nanoparticles were stabilized by adding dropwise TPP solution $(2 \mathrm{mg} / \mathrm{ml})$ to the $\beta$-GluNPs $(5 \mathrm{mg} / \mathrm{ml})$ in a magnetic stirrer at room temperature. The mixture stirred for $1 \mathrm{~h}$ at room temperature. At the end of incubation, the solution was spun in a centrifuge at $5000 \mathrm{rpm}$ and the pellet was washed with MilliQ water to remove unreacted nanoparticles and kept at $4^{\circ} \mathrm{C}$ for further use. 


\section{Characterization of $\beta$-GluNPs}

The characterization of $\beta$-Glucan and $\beta$-GluNPs were done by using high throughput instruments as follows

\section{${ }^{1} \mathrm{H}$ NMR analysis}

The synthesized $\beta$-Glu and $\beta$-GluNPs were dissolved in DMSO-d6. The dissolved sample poured into the NMR glass tube placed on the NMR JEOL. Nodel ECZ500-spectra were recorded with the 500 $\mathrm{MHz}$ spectrometer and the temperature was maintained at $80^{\circ} \mathrm{C}$. The ${ }^{1} \mathrm{H}$ NMR spectra in the 2000 total scan range (0-7 ppm) were recorded.

\section{FTIR Spectra analysis}

The synthesised $\beta$-Glu and $\beta$-GluNPs made as thin powders and mixed with $\mathrm{KBr}$ to make pellets. The pellets were analyzed on a Thermo-Nicolet 6700 -FTIR spectrophotometer in the infrared spectral range from $400-4000 \mathrm{~cm}^{-1}$.

\section{UV-Spectral analysis}

The $\beta$-GluNPs were dissolved in deionized water and poured in a glass cuvette was placed in Shimadzu MPC3600 UV-VIS spectrometer and UV range recorded from 200-500 nm

\section{Analysis of DLS and ZETA potential for $\beta$-GluNPs}

The $\beta$-GluNPs dissolved in deionized water and poured in a glass cuvette. The cuvette kept on the ZETA PALS and the temperature was maintained at $25^{\circ} \mathrm{C}$. The nanoparticle size and the distribution range polydispersity index (PDI) value was recorded.

\section{HR-TEM and SEM analysis for $\beta$-GluNPs}

The $\beta$-GluNPs desiccated for $12 \mathrm{~h}$. The desiccated nanoparticles were placed on the copper grid material on the Titan Themis 300kV from FEI, ULTRA 55 -GEMINI technology. The nanoparticles size, structure, and micrograph recorded.

\section{X-Ray Diffraction (XRD) for $\beta$-GluNPs}

The desiccated $\beta$-GluNPs, placed on the glass slide. The sample glass slide kept on the Rigaku Smart Lab general purpose X-ray diffractometer system. The diffraction intensities of the nanoparticles ranging from $10^{\circ}$ to $90^{\circ} 2 \theta$ angle were recorded.

\section{Antibacterial activity of $\beta$-GluNPs}

The bacterial cultures such as Staphylococcus aureus MTCC 96, Bacillus subtilis MTCC-2387, Pseudomonas aeruginosa MTCC 424 and Proteus vulgaris MTCC 426 were procured from Microbial Type 
Culture Collection (MTCC), Chandigarh. The antibacterial activity of $\beta$-GluNPs evaluated by using agar well diffusion method. The gel puncture used to cut the wells around $6 \mathrm{~mm}$ and swabbed with $0.1 \mathrm{ml}$ of bacterial pathogens at the concentration of $10^{8} \mathrm{CFU} / \mathrm{ml}$. The $\beta$-GluNPs was loaded in each wells at concentrations of 50,75 and $100 \mu \mathrm{g} / \mathrm{ml}$, respectively. The Ampicillin is used as a positive control and incubated at $37 \pm 0.2^{\circ} \mathrm{C}$. After $24 \mathrm{~h}$ incubation, the zone of inhibition $(\mathrm{mm})$ measured. The assay performed in triplicates with positive control.

\section{in vitro cytotoxicity assay for $\beta$-GluNPs}

\section{Cell viability analysis by MTT assay}

The breast cancer cell line MCF-7 used for assessing the cytotoxicity of the $\beta$-Glu and $\beta$-GluNPs by MTT assay. The MTT assay described in the earlier reports by Parthasarathy et al., (2020). The cells were treated with different concentrations of $\beta$-glu and $\beta$-GluNPs $(10,20,25,50,75,100,150$ and $200 \mu \mathrm{g} / \mathrm{mL})$ incubated for $48 \mathrm{~h}$ at $37^{\circ} \mathrm{C}$ in $5 \% \mathrm{CO}_{2}$. After incubation, $10 \mu \mathrm{L}$ of MTT reagent $(5 \mathrm{mg} / \mathrm{mL})$ added to each well, and the plates were incubated for at $37^{\circ} \mathrm{C}$ for $1 \mathrm{~h}$. Later, acidified isopropanol ( $\left.200 \mu \mathrm{L}\right)$ added to stop the reaction and again, the incubation done for $4 \mathrm{~h}$ to dissolve the purple formazan crystals produced. Molecular device USA ELISA plates were employed to read the absorbance at $595 \mathrm{~nm}$.

\section{Morphological characterization by (AO/PI) dual staining method}

Acridine orange and Propidium iodide (AO/PI) dual staining carried out to evaluate the morphological changes in the $\beta$-GluNPs $\left(\mathrm{IC}_{50}\right)$ treated cells. The AO/PI staining assay was described in the earlier reports by Parthasarathy et al., [27]. The seeded cells were treated with $\beta$-Glu nanoparticles ( $\mathrm{IC}_{50}$ concentration) for $24 \mathrm{~h}$. The cells labelled with 1:1 ratio of $A O / P I$ in phosphate buffer saline and allowed to stand for $10 \mathrm{~min}$. The leftover unbound dye discarded by washing in PBS. The cells were then filmed at 20X magnification using $485 \mathrm{~nm}$ excitation and $535 \mathrm{~nm}$ emission filter sets in a Zeiss inverted fluorescent microscope furnished with Axiovision ${ }^{\circledR}$ software. The data represented were in triplicates.

\section{DNA fragmentation assay:}

The DNA fragmentation assay for $\beta$-Glu and $\beta$-GluNPs treated MCF-7 cells were analysed by using agarose gel electrophoresis. Briefly, MCF-7 cells were seeded at a density of $3-4$ X10 cells/well in 6-well culture plates in $10 \%$ FBS-DMEM medium. The cells treated with $\mathrm{IC}_{50}$ concentration of $\beta$-GluNPs and solubilized in $0.4 \%$ DMSO for $24 \mathrm{~h}$. The treated cells collected after centrifugation for $5 \mathrm{~min}$ at $1000 \mathrm{Xg}$, washed with $50 \mathrm{mM}$ PBS (1 ml), and fixed in $70 \%(\mathrm{v} / \mathrm{v})$ ice-cold ethanol overnight. Following fixation, the cells spun in a centrifuge at $1000 \mathrm{Xg}$ for $5 \mathrm{~min}$ and dissolved in $40 \mu \mathrm{l}$ of phosphate buffer. Following centrifugation at $1000 \mathrm{Xg}$ for $5 \mathrm{~min}$, the supernatant subjected to speed vacuum concentration for $15 \mathrm{~min}$. Later, $3 \mu \mathrm{l}$ of $0.25 \%$ Nonidet P-40 and $3 \mu \mathrm{g}$ of RNase-A were added and incubated at $37^{\circ} \mathrm{C}$ for $30 \mathrm{~min}$. Moreover, proteinase $\mathrm{K}(3 \mu \mathrm{g})$ added consequently and incubated for another $30 \mathrm{~min}$ at $37^{\circ} \mathrm{C}$. Loading buffer $(12 \mu \mathrm{l})$ added to each sample and run on a $1.6 \%$ agarose gel for $2 \mathrm{~h}$ at $40 \mathrm{~V}$. DNA ladder $(1 \mathrm{~kb})$ employed as the reference. DNA viewed under UV light following EtBr staining $\left(0.5 \mu \mathrm{g} / \mathrm{ml}^{-1}\right)$. 


\section{Results And Discussion}

The extracted Beta-Glucan was $11.6 \mathrm{~g}$ from $100 \mathrm{~g}$ of Gracilaria corticate. Further, the generation of $\beta$ GluNPs, $\beta$-Glucan was solubilizing in $\mathrm{NaOH}$ under ambient conditions. The synthesised nanoparticles were elevated by tripolyphosphate, which relied on shape, structure uniformity, and stability of the nanoparticles. The synthesis of $\beta$-GluNPs was predicted by ${ }^{1} \mathrm{H}$ NMR signals, which were assigned to $\beta-$ Glucan and $\beta$-GluNPs and attributed to $\beta-1,6$-linkage. The ${ }^{1} \mathrm{H}$ signal at 3.39 assigned to the unlinked $\mathrm{H}-6$ of Glucan. The signal at 5.37 represented $\mathrm{H}-1$ phosphate attributed to the a-anomer of the reducing end. The appearance of peak at 5.38 PPM due to the $\mathrm{OH}-\mathrm{P}=\mathrm{O}$ binding in spectra Fig $1 \mathrm{~B}$, which confirms the $\beta$ glucan nanoparticle formation. The $\beta$-Glucan nanoparticles were in accordance with the signals of the similar compound reported in literature [28].

\section{UV analysis}

UV-Visible spectra showed strong surface plasmon resonance (SPR) peaks at $389 \mathrm{~nm}$ for the $\beta$-glucan nanoparticles stabilized at room temperature (Fig 3).

\section{FTIR analysis:}

The IR spectrum of $\beta$-Glucan showed eminent transmittance peaks at 3406.7, 2921.6, 2363.4, $1637.4,1453.3,1374.7,1253.2,1202.9,1153.2,1074.7,1045.8$ and 895.9. The strong peaks between 3406.7 corresponded to the $\mathrm{O}-\mathrm{H}$ stretching whereas peaks at $2921.6(\mathrm{C}-\mathrm{H}-)$ and 895.9 attributed to the $\beta-$ (1-6) linkages and $\beta$ Glu, respectively [29]. Besides, the peaks at 1637.4, 1453.3 and 1045.8 attributed to the $\mathrm{C}=\mathrm{O}, \mathrm{C}-\mathrm{H}, \mathrm{C}-\mathrm{O}$, respectively, representing the polysaccharide group [30]. (Figure.4). The IR spectrum of the synthesized $\beta$-GluNPs had peaks at 2506.6 attributed to the $\mathrm{OH}-\mathrm{P}=\mathrm{O}$ stretch, which implied the linkage between $\beta$-Glucan $\left(\mathrm{CH}_{2}-\mathrm{OH}\right)$ and the phosphoric group (TPP). The presence bands at 2506.4 and 895.3 implied the characteristic $\beta-(1-6)$ linkages and $\beta$-Glucan $[11,31]$.

\section{DLS and Zeta potential analysis}

The hydrostatic diameter of the $\beta$-GluNPs assessed by DLS confirming the particle size to be $88.91 \mathrm{~nm}$ and the particles were narrow sized and highly dispersed [Poly Dispersity Index- 0.225] (Figure 5a) The zeta potential was recorded as $-22.7 \mathrm{mV}$ that suggested the colloidal suspension of the nanoparticles. The negative effect could be due to TPP binding, which created repulsion forces on the nanoparticles (Figure 5b) [32, 33].

\section{XRD analysis}

The XRD pattern depicted the diffraction peaks of the $\beta$-GluNPs (Figure 6). The peaks corresponded to $2 \theta=23.08^{\circ}, 34.5^{\circ}, 45.2^{\circ}$, which were planes of crystalline nature of the GluNPs and were in accordance with the earlier reports on polysaccharides [34,35]

\section{HR-TEM analysis}


HR-TEM micrographs manifested the fine motifs of uniform sized $\beta$-GluNPs with a mean size of $20 \pm 5 \mathrm{~nm}$. The $\beta$-GluNPs were colloidal, circular shaped, with a smooth surface and durable for a long period (Figure 7a). SEM micrograph also revealed the circular shape and the smooth surface (Figure 7b). The well dispersed nanoparticles were observed in both SEM and HR-TEM mainly due to the presence of TPP involved in the formation of nanoparticles [36]. The HR-TEM and DLS size of the nanoparticles were variant due to the different techniques and principals involved.

\section{Antibacterial activity}

The antibacterial activity of the $\beta$-GluNPs evaluated against bacterial pathogens. The highest zone of inhibition was perceived in B.subtilis $(15 \mathrm{~mm})$ followed by S.aureus $(12 \mathrm{~mm})$ and P.aeruginosa (12 $\mathrm{mm}$ ). The slightest activity was observed in P.vulgaris $(10 \mathrm{~mm}$ ) (Figure 8). From the obtained results, known that $\beta$-GluNPs performed excellent activity against both gram positive and gram-negative bacterial pathogens. But, when compared with Gram negative the $\beta$-GluNPs have potential antibacterial activity against gram positive bacterial pathogens, due to variance in the membrane structure thickness in grampositive and gram-negative also influence the bactericidal activity of $\beta$-GluNPs $[37,38]$.

\section{in-vitro anticancer activity}

The cytotoxicity effect of the $\beta$-GluNPs assessed against MCF-7 breast cancer cell line in a dosedependent manner $(10,20,25,50,75,100$ and $150 \mu \mathrm{g} / \mathrm{ml})$. The effect of nanoparticles at different concentrations revealed by the cell death observed and $I_{50}$ values were $42.5 \mu \mathrm{g} / \mathrm{ml}$ and $52.6 \mu \mathrm{g} / \mathrm{ml}$ for $\beta$ GluNPs and $\beta$-Glucan, respectively (Figure 9). These results proposed that the cytotoxicity efficacies of the synthesised $\beta$-GluNPs were stronger than free $\beta$-Glu, which described an increased anticancer efficiency of $\beta$-Glucan nanoform. This might have been due to the shape, structure, and surface functionalization as well as the high penetrable nature of the nanoparticles that accumulated inside the cancer cells and generated stress, which finally led to cell death [39]. Similarly, Yugay, et al. [24] reported that metal-coated beta-Glucan nanoparticles exhibited cytotoxicity against the cancer cells. The apoptosis effect due to Glucan triggered the immune system, which ultimately led to the programmed cell death and reduced tumor resistance $[40,41]$.

The competence of $\beta$-GluNPs to induce apoptosis ascertained by AO/PI staining. Figure 11 shows the stained cells that were characterized as viable cells in light green while showing undamaged nuclear structure. Early apoptotic cells were indicated by orange fluorescence while the late apoptotic cells, were shown in red color indicating the shrinking cell density with nuclei condensation and membrane blebbing in contrast. Apoptosis is programmed cell death caused by genetic and structural alterations [42, 43]. The induction of apoptosis in cancer cells is the crucial characteristic of several anticancer agents.

The treated cells' DNA fragmentation pattern was analysed, to confirm that the MCF 7 cell death induced by $\beta$-GluNPs was via apoptosis and not via necrosis, The characteristic ladder pattern on the agarose gels, which is the result of the endonuclease mediated inter nucleosomal chromosomal DNA fragmentation, is the key biochemical sign of apoptosis (Figure 12). In necrotic cell death, random 
fragmentation of chromosomal DNA results in fragments, which give a smear like appearance on agarose gels. $\beta$-GluNPs treatment induced inter nucleosomal DNA fragmentation at the $\mathrm{IC}_{50}-85.5 \mu \mathrm{g} / \mathrm{ml}$ concentration [44].

\section{Conclusion}

To Sum up, the $\beta$-GluNPs were found to inhibit the bacterial pathogens and trigger apoptosis in MCF-7 cells by an increase in inter chromosomal DNA fragmentation. DNA fragmentation, a biochemical hallmark of apoptosis assumed the terminal step in the apoptosis cascade. The results of the present study have provided a strong evidence on the capability of the $\beta$-glu nanoparticles to enhance genomic DNA fragmentation resulting in the typical DNA ladder pattern in treated Hela cells. All these results indicated the potential of $\beta$-GluNPs in inducing apoptosis of MCF-cells. Further studies to find the mechanism of apoptosis of MCF- cells is under process.

\section{Declarations}

\section{Ethical Approval}

Not Applicable

\section{Consent to Participate}

Not Applicable

\section{Consent to Publish}

Not Applicable

\section{Authors Contributions}

Ramalingam Parthasarathy: Conceptualization, Methodology, Writing - original draft. Seetharaman Prabu Kumar. Writing- review \& editing - original draft. H.C. Yashavantha Rao: Writing - review \& editing. Chelliah Jayabaskaran: Supervision, Project administration,

\section{Funding}

This study was supported by a grant from the Department of Science and Technology-Science and Engineering Research Board (DST-SERB) Govt. of India, New Delhi (Ref. no. PDF/2017/001184). Dr. R. Parthasarathy thank DST-SERB for financial support.

\section{Competing Interests}

The authors declare that they have no known competing financial interests 
Not Applicable

\section{References}

1. Gajendiran, M., Choi, J., Kim, S. J., Kim, K., Shin, H., Koo, H. J., \& Kim, K. (2017). Conductive biomaterials for tissue engineering applications. Journal of Industrial and Engineering Chemistry. https://doi.org/10.1016/j.jiec.2017.02.031.

2. Esparza-Soto, M., \& Westerhoff, P. (2003). Biosorption of humic and fulvic acids to live activated sludge biomass. Water Research, 37(10). https://doi.org/10.1016/S0043-1354(02)00630-9.

3. Liu, J., Qin, G., Raveendran, P., \& Ikushima, Y. (2006). Facile "green" synthesis, characterization, and catalytic function of $\beta$-D-glucose-stabilized Au nanocrystals. Chemistry - A European Journal, 12(8). https://doi.org/10.1002/chem.200500925.

4. Balantrapu, K., \& Goia, D. V. (2009). Silver nanoparticles for printable electronics and biological applications. Journal of Materials Research, 24(9). https://doi.org/10.1557/jmr.2009.0336.

5. Li, J., Cai, C., Yang, C., Li, J., Sun, T., \& Yu, G. (2019). Recent Advances in Pharmaceutical Potential of Brown Algal Polysaccharides and their Derivatives. Current Pharmaceutical Design, 25(11). https://doi.org/10.2174/1381612825666190618143952.

6. Husemann, E. (1968). Book Review: Chemistry and Enzymology of Marine Algal Polysaccharides. By Percival, E., \& McDowell, R. H. Angewandte Chemie International Edition in English, 7(9). https://doi.org/10.1002/anie.196807463.

7. $\beta$-glucan barley on visceral fat obesity in Japanese individuals: A randomized, double-blind study. Nutrition, 42. https://doi.org/10.1016/j.nut.2017.05.002.

8. Vetvicka, V., Vannucci, L., Sima, P., \& Richter, J. (2019). Beta glucan: Supplement or drug? From laboratory to clinical trials. Molecules. https://doi.org/10.3390/molecules24071251.

9. Sathiyabama, M., \& Parthasarathy, R. (2016). Biological preparation of chitosan nanoparticles and its in vitro antifungal efficacy against some phytopathogenic fungi. Carbohydrate Polymers, 151. https://doi.org/10.1016/j.carbpol.2016.05.033.

10. Sathiyabama, M., \& Manikandan, A. (2016). Chitosan nanoparticle induced defense responses in fingermillet plants against blast disease caused by Pyricularia grisea (Cke.) Sacc. Carbohydrate Polymers, 154. https://doi.org/10.1016/j.carbpol.2016.06.089.

11. Anusuya, S., \& Sathiyabama, M. (2014). Preparation of $\beta$-d-glucan nanoparticles and its antifungal activity. International Journal of Biological Macromolecules, 70.

https://doi.org/10.1016/j.jibiomac.2014.07.011.

12. Sokolova, R. V., Ermakova, S. P., Awada, S. M., Zvyagintseva, T. N., \& Kanaan, H. M. (2011). Composition, structural characteristics, and antitumor properties of polysaccharides from the brown algae Dictyopteris polypodioides and Sargassum sp. Chemistry of Natural Compounds, 47(3). https://doi.org/10.1007/s10600-011-9925-1. 
13. Daou, C., \& Zhang, H. (2012). Oat Beta-Glucan: Its Role in Health Promotion and Prevention of Diseases. Comprehensive Reviews in Food Science and Food Safety, 11(4). https://doi.org/10.1111/j.1541-4337.2012.00189.x.

14. Liang, J., Melican, D., Cafro, L., Palace, G., Fisette, L., Armstrong, R., \& Patchen, M. L. (1998). Enhanced clearance of a multiple antibiotic resistant Staphylococcus aureus in rats treated with PGG-glucan is associated with increased leukocyte counts and increased neutrophil oxidative burst activity. International Journal of Immunopharmacology, 20(11). https://doi.org/10.1016/S01920561(98)00007-1.

15. Kaiser, A. B., \& Kernodle, D. S. (1998). Synergism between poly-(1-6)- $\beta$-D-glucopyranosyl-(1-3)- $\beta$-Dglucopyranose glucan and cefazolin in prophylaxis of staphylococcal wound infection in a guinea pig model. Antimicrobial Agents and Chemotherapy, 42(9). https://doi.org/10.1128/aac.42.9.2449.

16. Das, A., Salloum, F. N., Xi, L., Rao, Y. J., \& Kukreja, R. C. (2009). ERK phosphorylation mediates sildenafil-induced myocardial protection against ischemia-reperfusion injury in mice. American Journal of Physiology - Heart and Circulatory Physiology, 296(5). https://doi.org/10.1152/ajpheart.00100.2009.

17. Misra, R., Acharya, S., \& Sahoo, S. K. (2010). Cancer nanotechnology: Application of nanotechnology in cancer therapy. Drug Discovery Today. https://doi.org/10.1016/j.drudis.2010.08.006.

18. Farnsworth, N. R., \& Soejarto, D. D. (1985). Potential consequence of plant extinction in the United States on the current and future availability of prescription drugs. Economic Botany, 39(3). https://doi.org/10.1007/BF02858792.

19. Nakkala, J. R., Mata, R., Gupta, A. K., \& Sadras, S. R. (2014). Biological activities of green silver nanoparticles synthesized with Acorous calamus rhizome extract. European Journal of Medicinal Chemistry, 85. https://doi.org/10.1016/j.ejmech.2014.08.024.

20. Parveen, S., \& Sahoo, S. K. (2008). Polymeric nanoparticles for cancer therapy. Journal of Drug Targeting. https://doi.org/10.1080/10611860701794353.

21. Singhal, S., Nie, S., \& Wang, M. D. (2010). Nanotechnology applications in surgical oncology. Annual Review of Medicine. https://doi.org/10.1146/annurev.med.60.052907.094936.

22. Yezhelyev, M. V., Gao, X., Xing, Y., Al-Hajj, A., Nie, S., \& O’Regan, R. M. (2006). Emerging use of nanoparticles in diagnosis and treatment of breast cancer. Lancet Oncology. https://doi.org/10.1016/S1470-2045(06)70793-8.

23. RSC Advances, 5(109). https://doi.org/10.1039/c5ra15060d.

24. Carbohydrate Polymers, 245. https://doi.org/10.1016/j.carbpol.2020.116547.

25. Exbrayat, J. M., Moudilou, E. N., \& Lapied, E. (2015). Harmful Effects of Nanoparticles on Animals. Journal of Nanotechnology. https://doi.org/10.1155/2015/861092.

26. Ghormade, V., Deshpande, M. V., \& Paknikar, K. M. (2011). Perspectives for nano-biotechnology enabled protection and nutrition of plants. Biotechnology Advances. https://doi.org/10.1016/j.biotechadv.2011.06.007. 
27. Parthasarathy, R., Chandrika, M., Yashavantha Rao, H. C., Kamalraj, S., Jayabaskaran, C., \& Pugazhendhi, A. (2020). Molecular profiling of marine endophytic fungi from green algae: Assessment of antibacterial and anticancer activities. Process Biochemistry, 96. https://doi.org/10.1016/j.procbio.2020.05.012.

28. Kim, Y. T., Kim, E. H., Cheong, C., Williams, D. L., Kim, C. W., \& Lim, S. T. (2000). Structural characterization of $\beta$-D-( $(\rightarrow 3,1 \rightarrow 6)$-linked glucans using NMR spectroscopy. Carbohydrate Research, 328(3). https://doi.org/10.1016/S0008-6215(00)00105-1.

29. Zlatković, D., Jakovljević, D., Zeković, D., \& Vrvić, M. M. (2003). A glucan from active dry baker's yeast (Saccharomyces cerevisiae): A chemical and enzymatic investigation of the structure. Journal of the Serbian Chemical Society, 68(11). https://doi.org/10.2298/JSC0311805Z.

30. Gidley, M., \& Grant Reid, J. (2006). Galactomannans and Other Cell Wall Storage Polysaccharides in Seeds. In Food Polysaccharides and Their Applications. https://doi.org/10.1201/9781420015164.ch6.

31. Mathlouthi, M., \& Koenig, J. L. (1987). Vibrational spectra of carbohydrates. Advances in Carbohydrate Chemistry and Biochemistry, 44(C). https://doi.org/10.1016/S0065-2318(08)60077-3.

32. Wu, Y., Yang, W., Wang, C., Hu, J., \& Fu, S. (2005). Chitosan nanoparticles as a novel delivery system for ammonium glycyrrhizinate. International Journal of Pharmaceutics, 295(1-2). https://doi.org/10.1016/j.ijpharm.2005.01.042.

33. Khlebtsov, B. N., \& Khlebtsov, N. G. (2011). On the measurement of gold nanoparticle sizes by the dynamic light scattering method. Colloid Journal, 73(1). https://doi.org/10.1134/S1061933X11010078.

34. Qi, L., Xu, Z., Jiang, X., Hu, C., \& Zou, X. (2004). Preparation and antibacterial activity of chitosan nanoparticles. Carbohydrate Research, 339(16). https://doi.org/10.1016/j.carres.2004.09.007.

35. Tripathi, S., Mehrotra, G. K., \& Dutta, P. K. (2009). Physicochemical and bioactivity of cross-linked chitosan-PVA film for food packaging applications. International Journal of Biological Macromolecules, 45(4). https://doi.org/10.1016/j.ijbiomac.2009.07.006.

36. Piani, L., \& Papo, A. (2013). Sodium tripolyphosphate and polyphosphate as dispersing agents for alumina suspensions: Rheological characterization. Journal of Engineering (United Kingdom), 2013. https://doi.org/10.1155/2013/930832.

37. Shrivastava, S., Bera, T., Roy, A., Singh, G., Ramachandrarao, P., \& Dash, D. (2007). Characterization of enhanced antibacterial effects of novel silver nanoparticles. Nanotechnology. https://doi.org/10.1088/0957-4484/18/22/225103.

38. Zarina, A., \& Nanda, A. (2014). Green approach for synthesis of silver nanoparticles from marine streptomyces- MS 26 and their antibiotic efficacy. Journal of Pharmaceutical Sciences and Research, 6(10).

39. Nel, A., Xia, T., Mädler, L., \& Li, N. (2006). Toxic potential of materials at the nanolevel. Science. https://doi.org/10.1126/science.1114397. 
40. Chan, W. K., Cheung, C. C. H., Law, H. K. W., Lau, Y. L., \& Chan, G. C. F. (2008). Ganoderma lucidum polysaccharides can induce human monocytic leukemia cells into dendritic cells with immunostimulatory function. Journal of Hematology and Oncology, 1(1). https://doi.org/10.1186/17568722-1-9.

41. Kidd, P. M. (2000). The use of mushroom glucans and proteoglycans in cancer treatment. Alternative Medicine Review.

42. Li, Q. F., Shi, S. L., Liu, Q. R., Tang, J., Song, J., \& Liang, Y. (2008). Anticancer effects of ginsenoside Rg1, cinnamic acid, and tanshinone IIA in osteosarcoma MG-63 cells: Nuclear matrix downregulation and cytoplasmic trafficking of nucleophosmin. International Journal of Biochemistry and Cell Biology, 40(9). https://doi.org/10.1016/j.biocel.2008.01.031.

43. Ott, M., Gogvadze, V., Orrenius, S., \& Zhivotovsky, B. (2007). Mitochondria, oxidative stress and cell death. Apoptosis. https://doi.org/10.1007/s10495-007-0756-2.

44. Biomaterials, 32(4). https://doi.org/10.1016/j.biomaterials.2010.10.030.

\section{Figures}

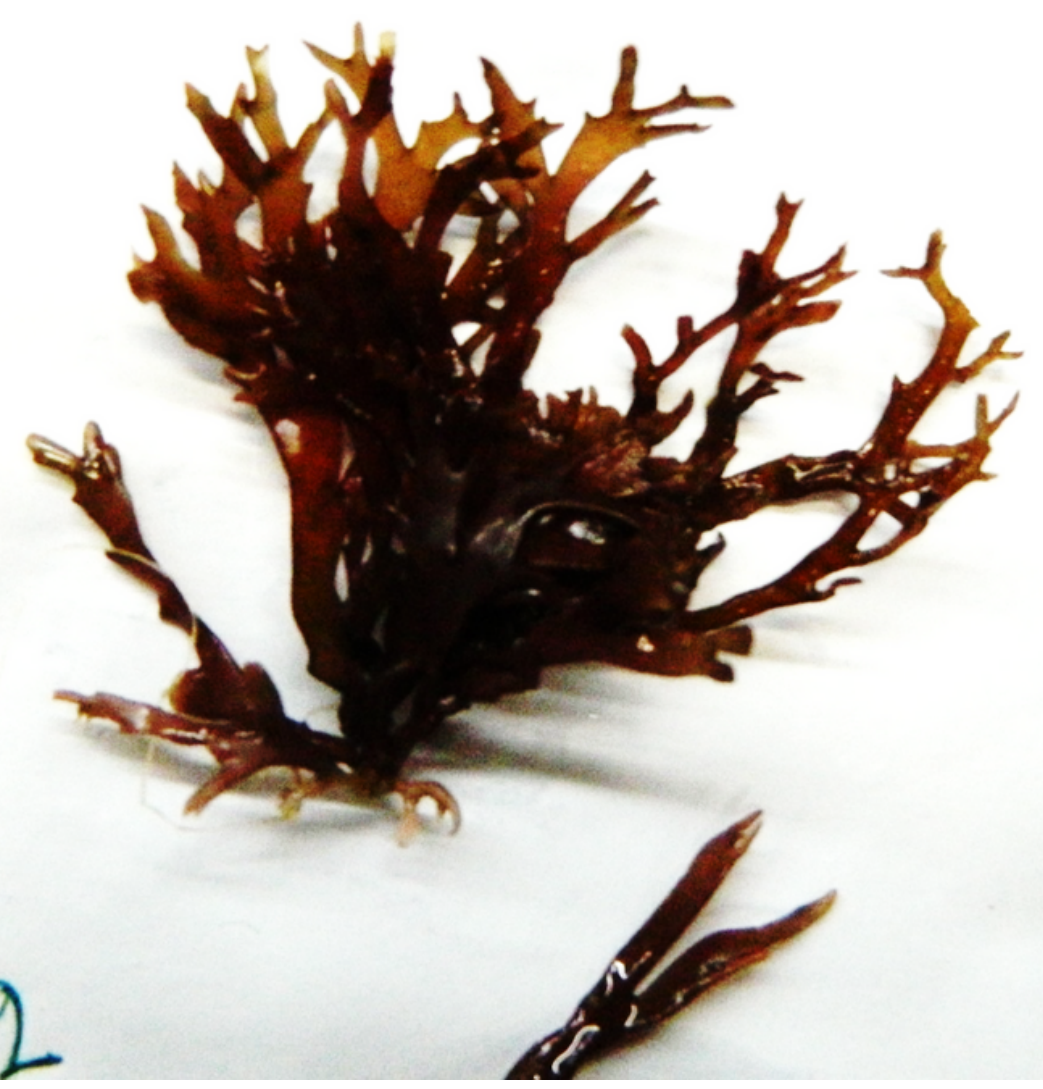


Figure 1

Image of Gracilaria corticate
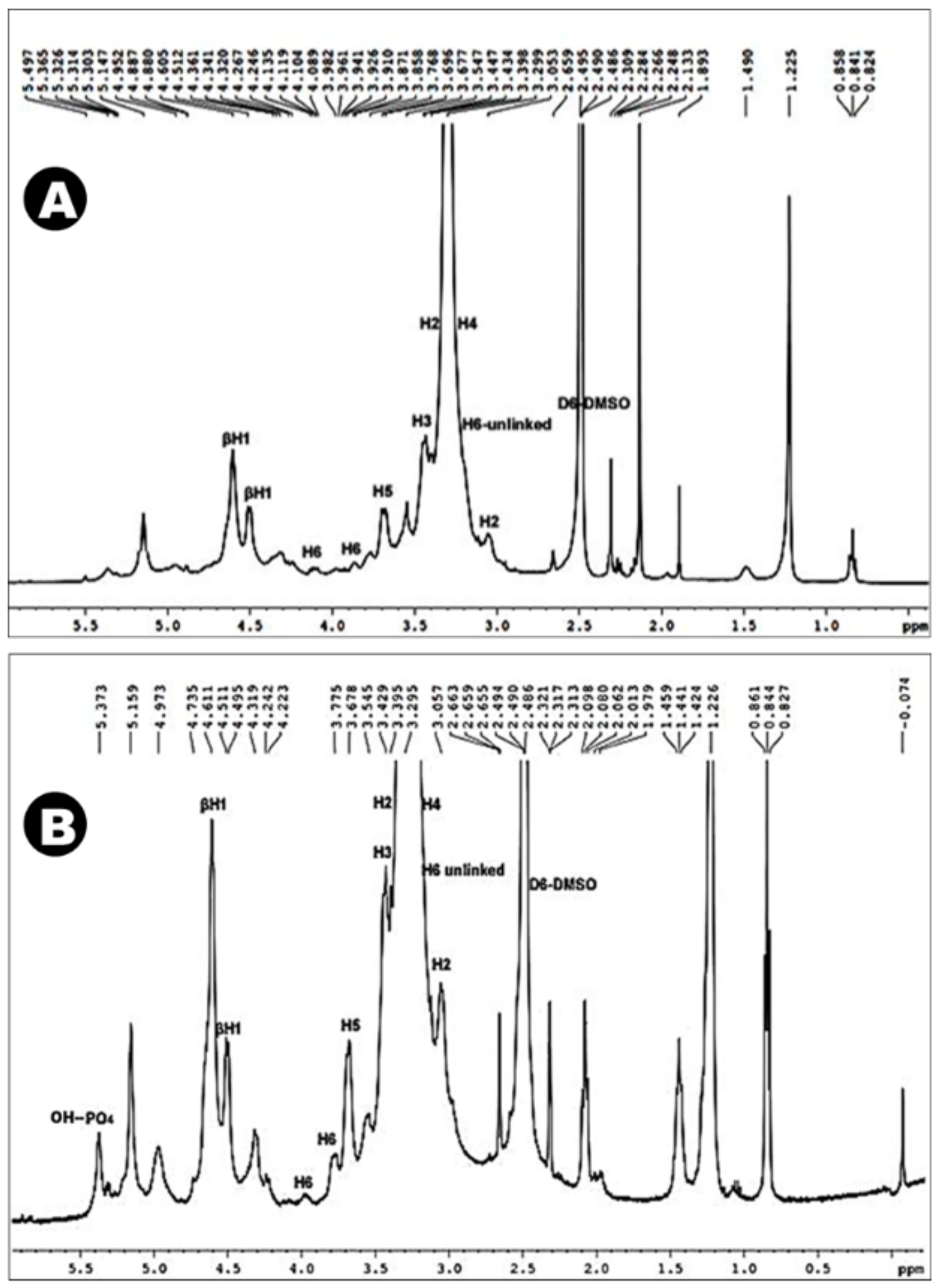

Figure 2

(A) $\beta$-glucan extraction from marine algae and (B) $\beta$-GluNPs formation revealed by $1 \mathrm{H}$ NMR. 


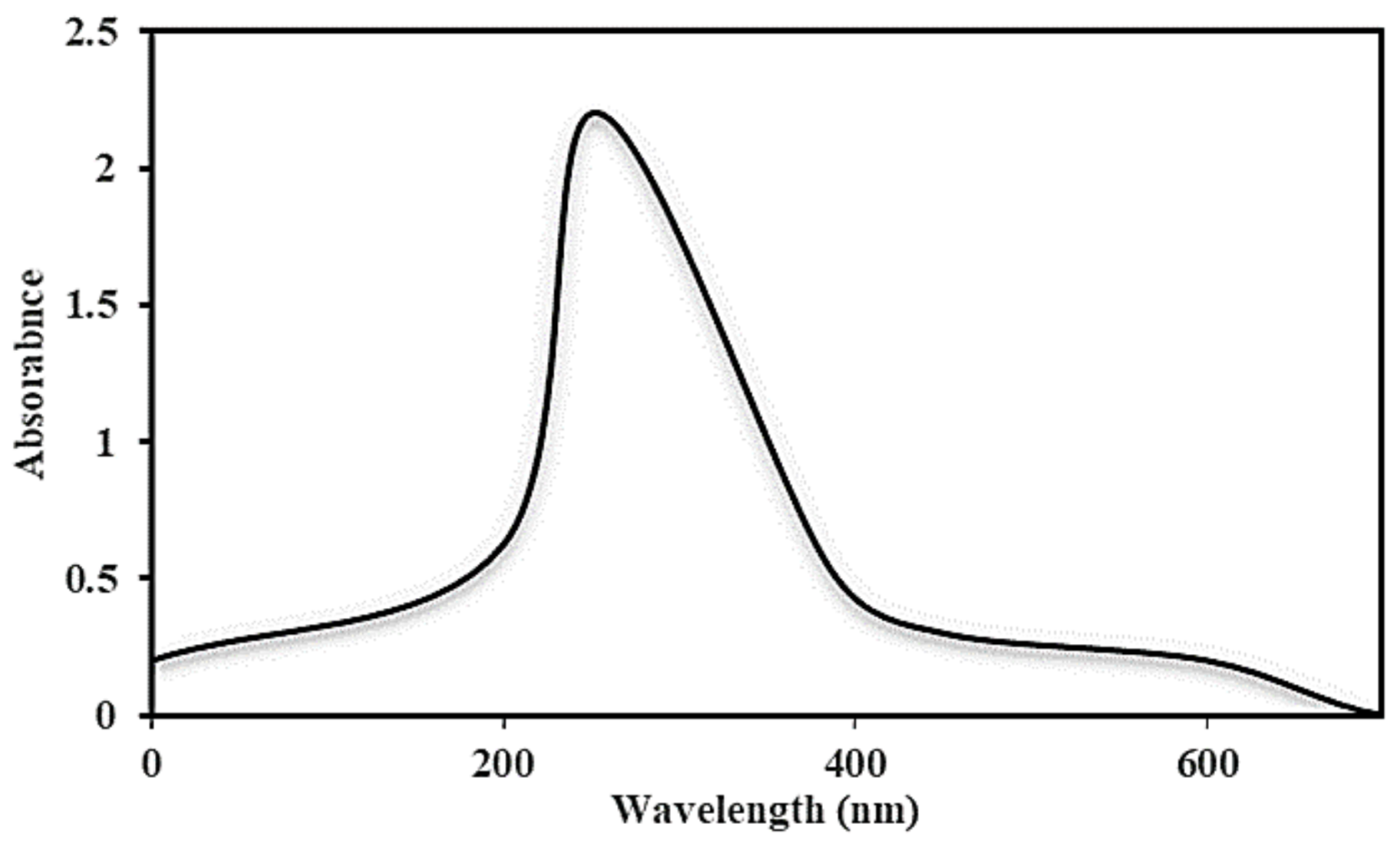

Figure 3

UV-Visible spectra- surface plasmon resonance (SPR) peaks of $\beta$-GluNPs 


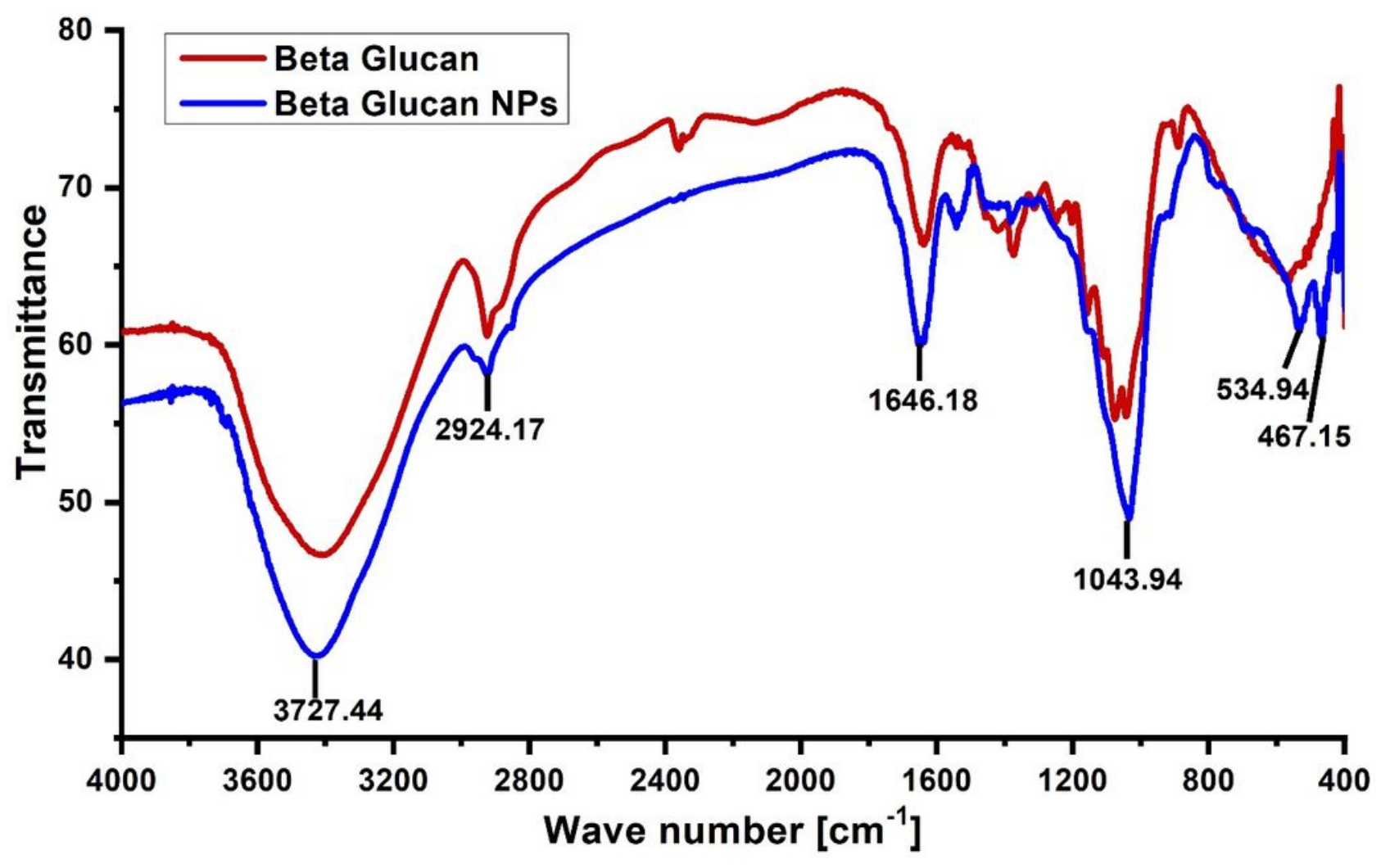

Figure 4

FTIR spectrum for extracted $\beta$-glucan and $\beta$-GluNPs 
Results

$\begin{array}{rlllll} & & & \text { Size }(\mathbf{d} . \mathbf{n m}): & \% \text { Intensity } & \text { Width (d.n... } \\ \text { Z-Average (d.nm): } & 89.81 & \text { Peak 1: } & 115.4 & 100.0 & 48.82 \\ \text { Pdl: } & 0.225 & \text { Peak 2: } & 0.000 & 0.0 & 0.000 \\ \text { Intercept: } & 0.924 & \text { Peak 3: } & 0.000 & 0.0 & 0.000\end{array}$

Result quality : Good

Size Distribution by Intensity

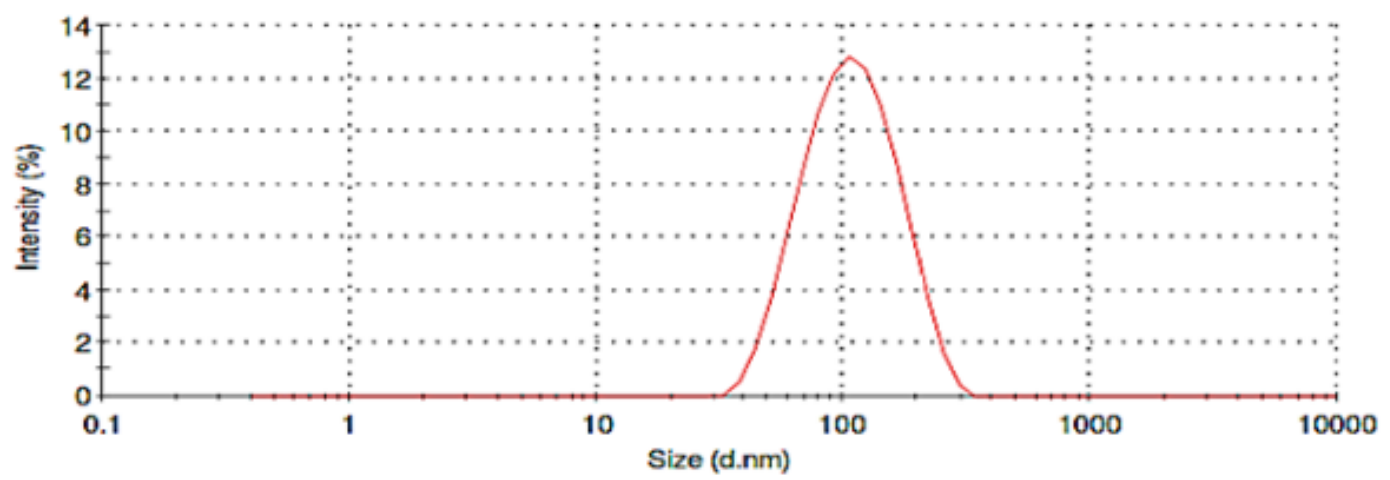

Fecord 23: AP 1

\section{Results}

Zeta Potential (mV): -22.7

Zeta Deviation ( $\mathrm{mV}$ ): $\mathbf{5 . 4 7}$

Conductivity $(\mathrm{mS} / \mathrm{cm}): 1.08$

Result quality : Good

$\begin{array}{llll} & \text { Mean }(\mathrm{mV}) & \text { Area }(\%) & \text { Width }(\mathrm{mV}) \\ \text { Peak 1: } & -22.7 & 100.0 & 5.47 \\ \text { Peak 2: } & 0.00 & 0.0 & 0.00 \\ \text { Peak 3: } & 0.00 & 0.0 & 0.00\end{array}$

Zeta Potential Distribution

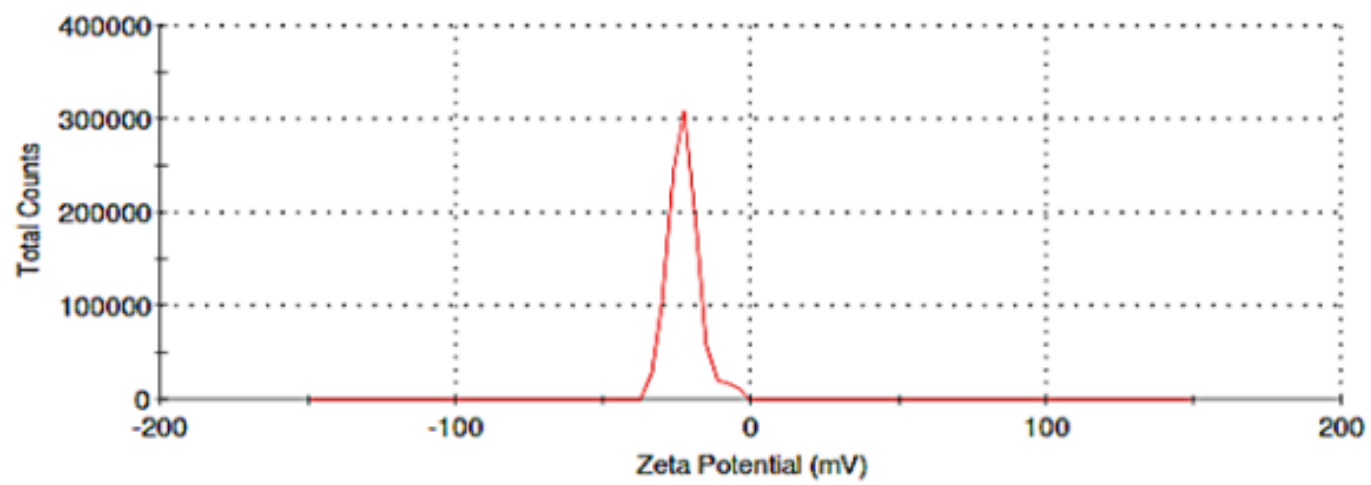

Record 32: NF 1

\section{Figure 5}

(a) Dynamic light scattering (DLS) of the $\beta$-GluNPs. (b) The zeta potential in aqueous solution estimated by particle character. 


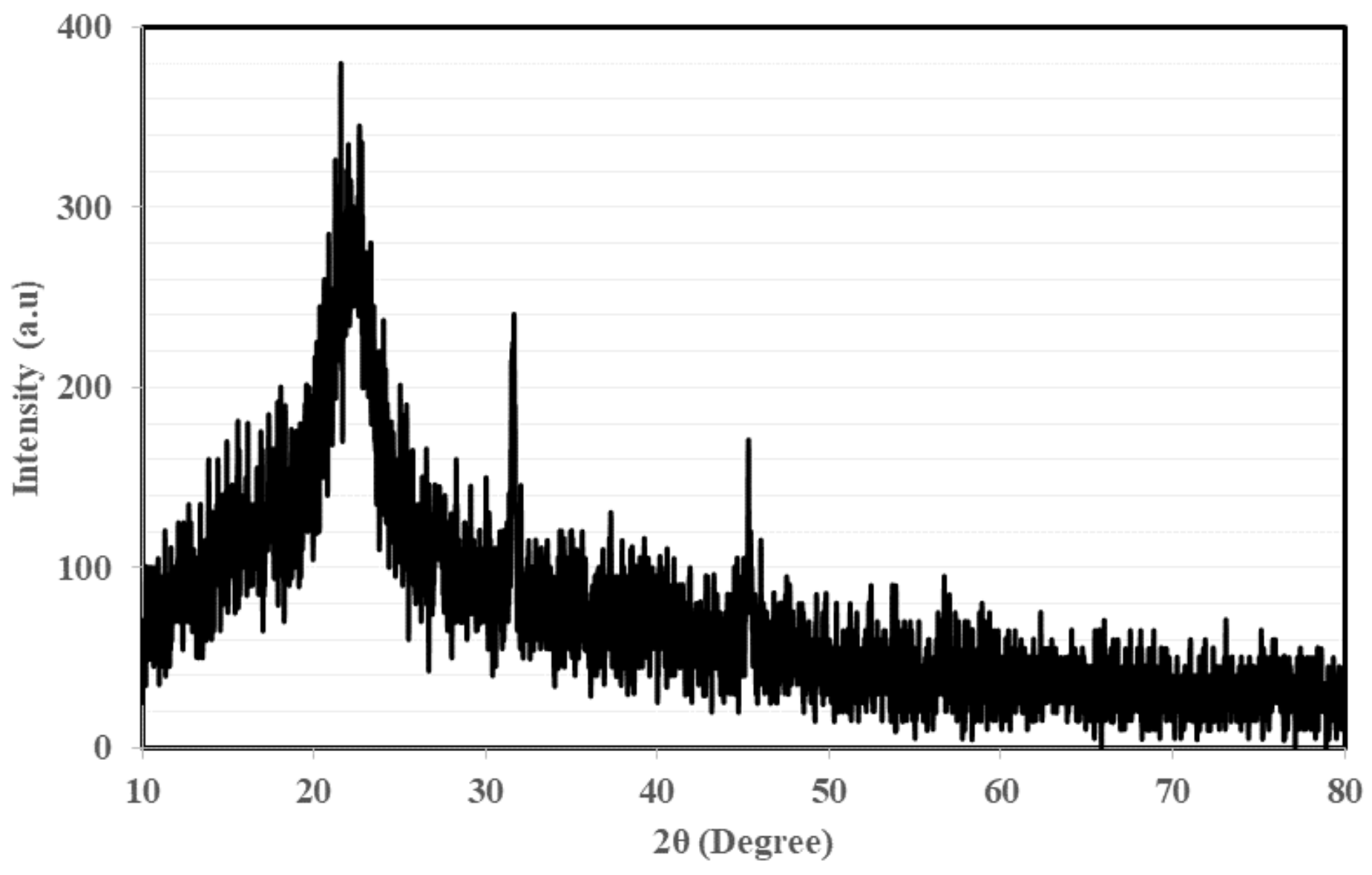

Figure 6

XRD analysis for $\beta$-GluNPs 


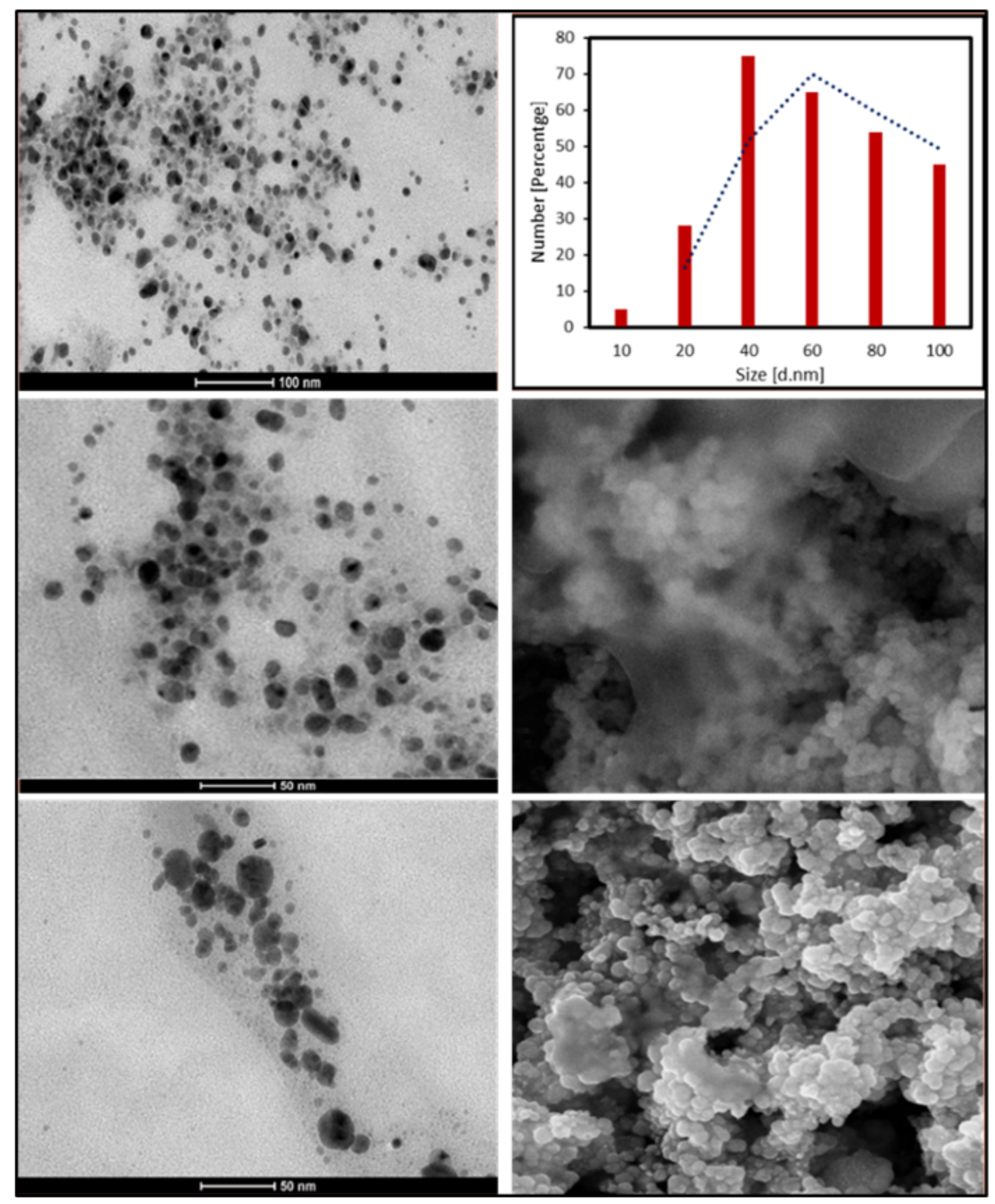

Figure 7

(a) HRTEM micrograph of $\beta$-GluNPs (scale bar $=100,50 \mathrm{~nm}$ ) with Particle size histogram (b) SEM micrograph of $\beta$-GluNPs. 

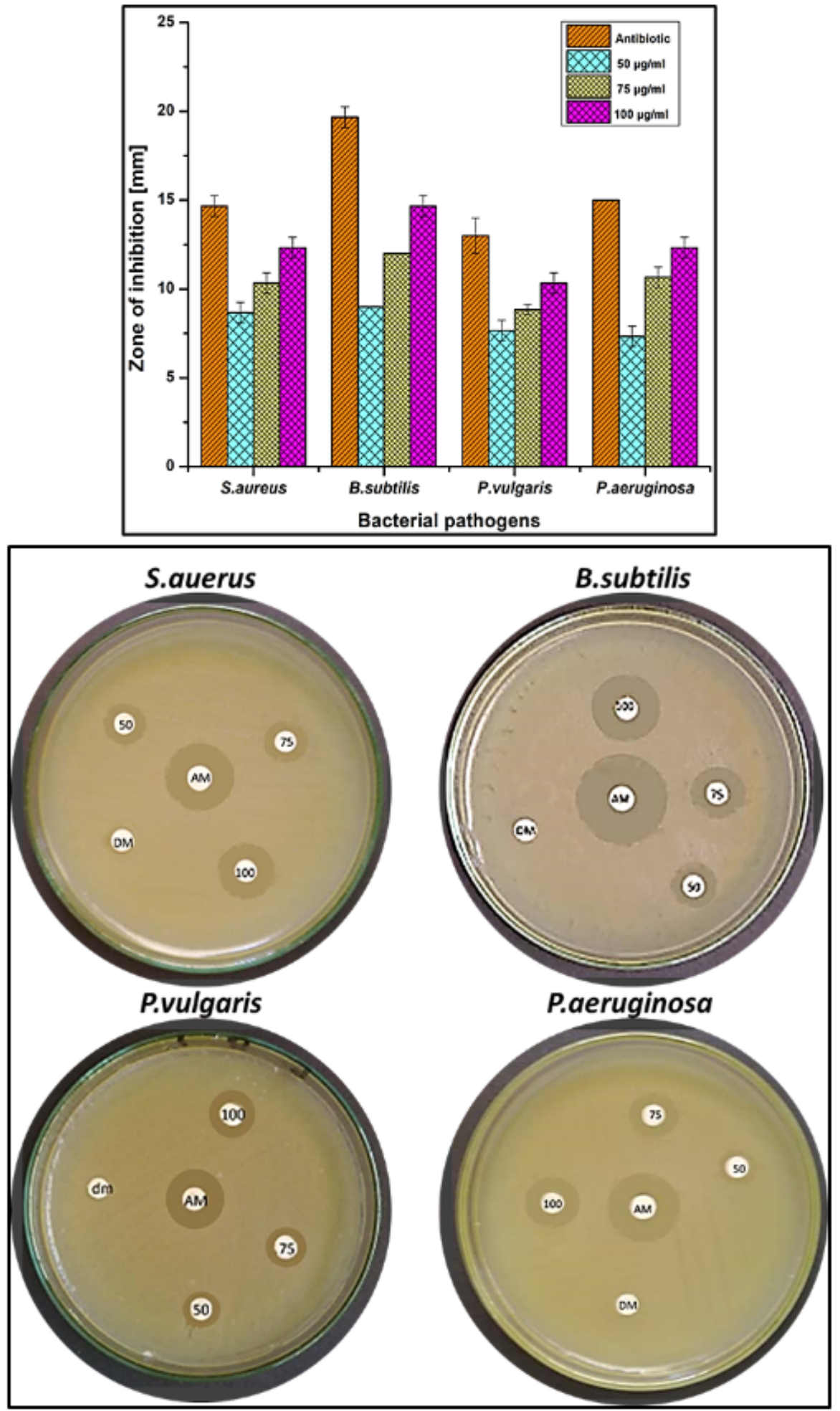

Figure 8

Antibacterial activity of $\beta$-GluNPs 


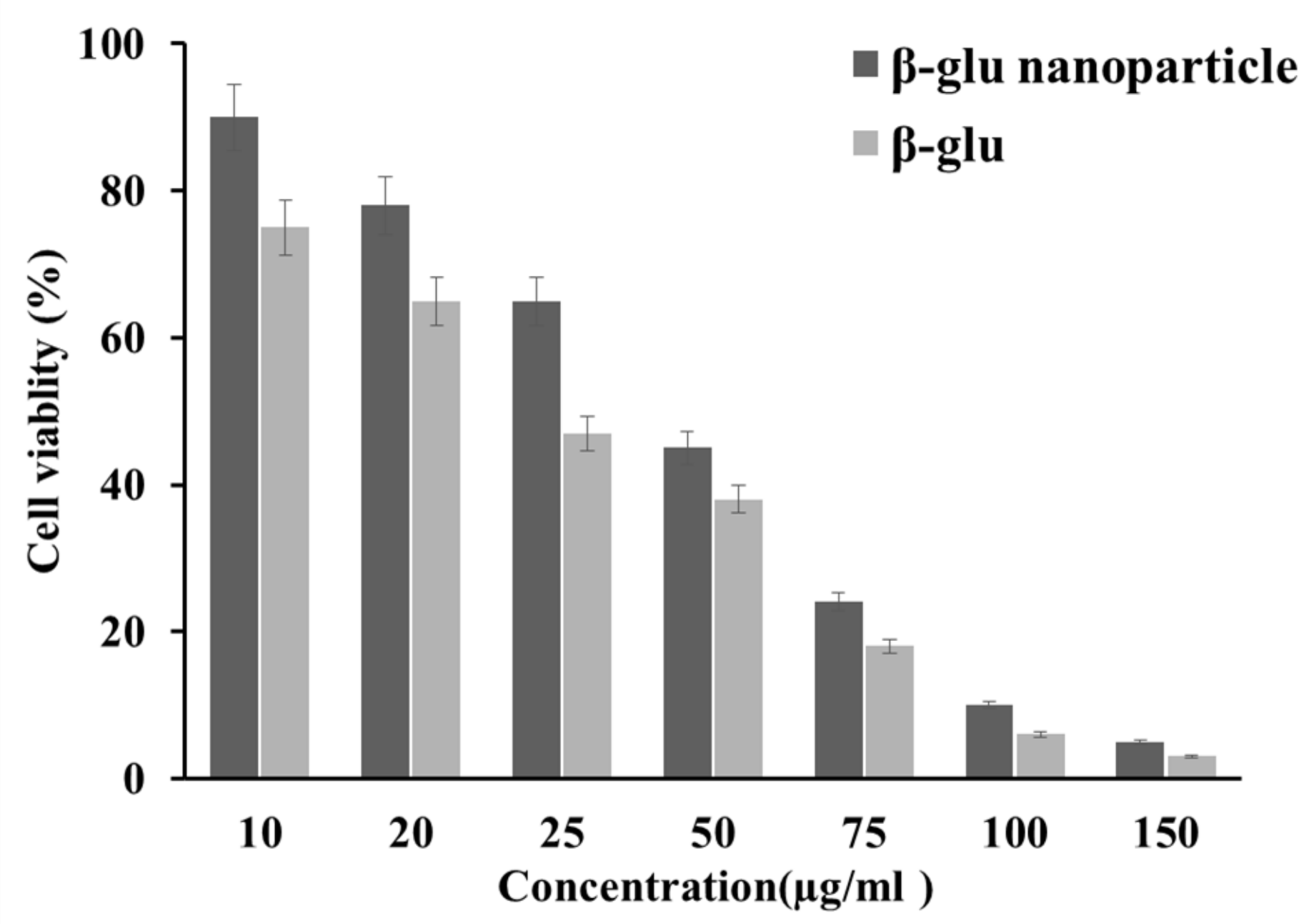

Figure 9

MTT assay for $\beta$-Glucan and $\beta$-GluNPs

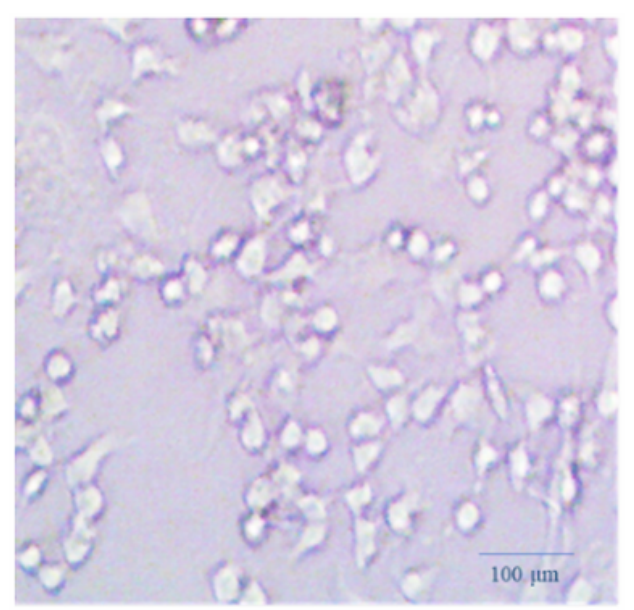

Control

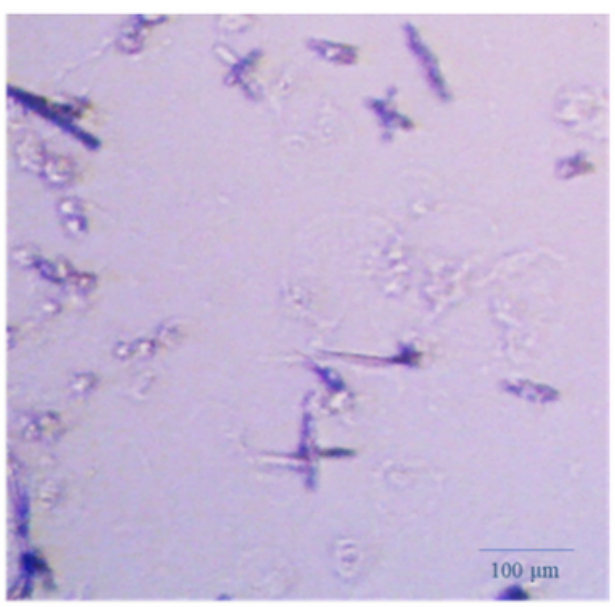

$\beta$-Glu Treated

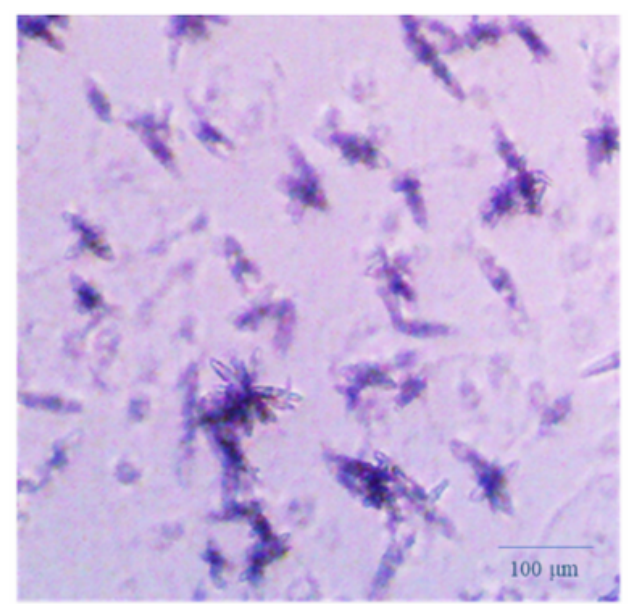

$\beta$-GluNPs Treated

Figure 10 
Microscopic observation of treated and control, MCF-7 breast cancer cells

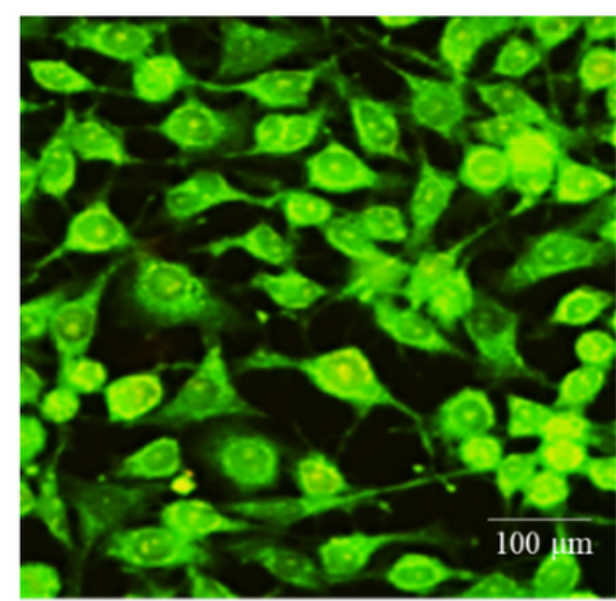

Control

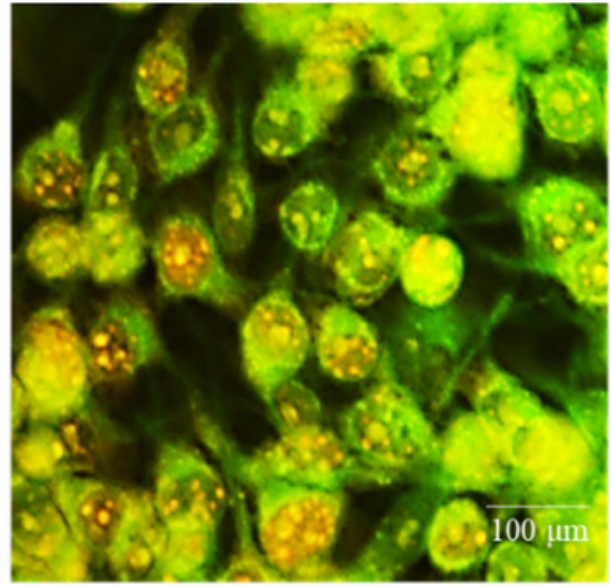

$\beta$-Glu Treated

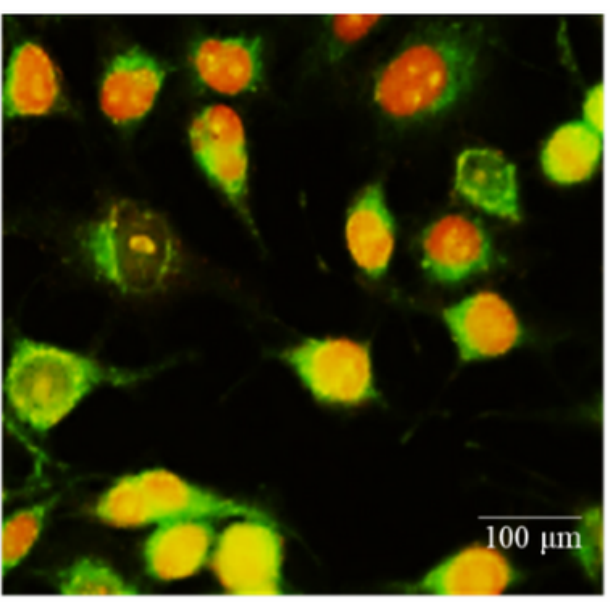

$\beta$-GluNPs Treated

Figure 11

$\mathrm{AO} / \mathrm{PI}$ dual staining assay 


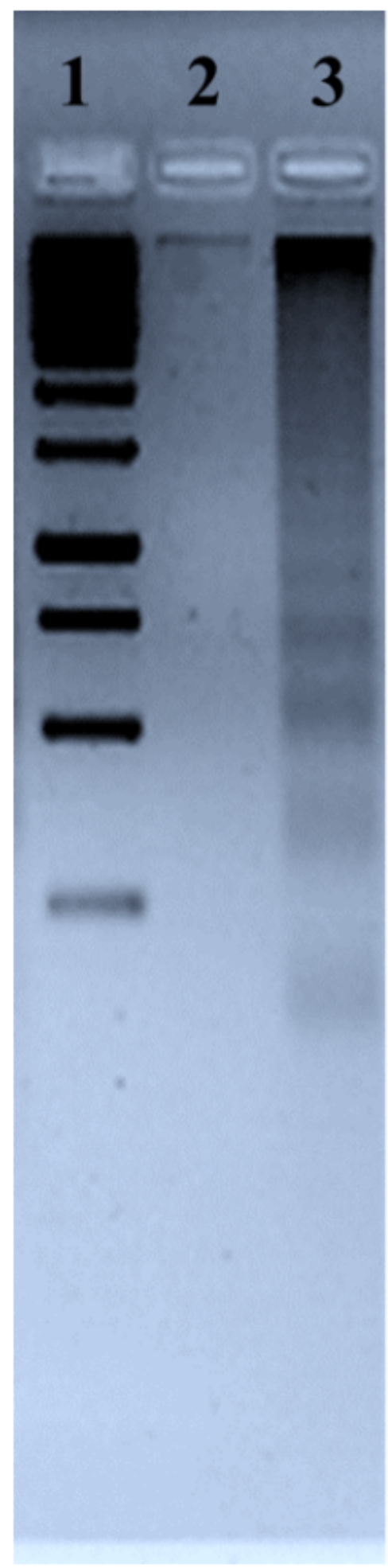

Figure 12

DNA fragmentation assay (1) DNA marker; (2) Control; and (3) $\beta$-GluNPs treated cells 